\title{
A VIOLAÇÃO DOS DIREITOS FUNDAMENTAIS NO SISTEMA PRISIONAL BRASILEIRO À LUZ DA TEORIA DO GARANTISMO PENAL
}

\section{THE VIOLATION OF FUNDAMENTAL RIGHT IN THE BRAZILIAN SYSTEM PRISON IN THE LIGHT OF THE THEORY OF CRIMINAL GARANTISM}

\begin{abstract}
CAMILA MARIA ROSA CASARI
Mestranda em Ciências Jurídicas pela Universidade Estadual do Norte do Paraná (Uenp). Especialista em Direito Público pela Universidade para o Desenvolvimento do Estado e da Região do Pantanal (Uniderp). Professora na União das Instituições Educacionais do Estado de São Paulo Uniesp - Faculdade de Araraquara (Fara). Assessora Jurídica do Município de Boa Esperança do Sul - SP e advogada.
\end{abstract} camilarcasari@gmail.com

GILBERTO GIACÓIA

Pós-doutor pelas Faculdades de Direitos das Universidades de Coimbra (2001) e Barcelona (2010), doutor em Direito Penal pela Universidade de São Paulo. É professor associado na graduação e na pós-graduação da Faculdade de Direito de Jacarezinho, que integra a Universidade do Norte do Paraná (Uenp). Integrante do Ministério Público do Estado do Paraná desde 1980. Foi procurador-geral de Justiça, de 1998 a 2000, tendo presidido o Conselho Nacional de Procuradores-Gerais de Justiça (CNPG), de 1999 a 2000. giacoia@brturbo.com.br

\section{RESUMO}

0 indivíduo que comete uma infração penal em um Estado Democrático de Direito, após ser devidamente processado e condenado a cumprir pena privativa de liberdade, respeitando-se os princípios constitucionais, somente será destituído do bem jurídico liberdade. Não há qualquer legitimidade e fere a finalidade da aplicação da pena, qualquer espécie de desrespeito aos direitos fundamentais do preso. Contudo, de forma reiterada o sistema prisional brasileiro viola direitos fundamentais, muito além da privação da liberdade. Este trabalho propõe-se a analisar a ocorrência e quais as consequências das violações dos direitos fundamentais dos presos à luz da teoria do garantismo penal, na perspectiva desenvolvida pelo doutrinador Luigi Ferrajoli, propondo que o Estado desenvolva políticas criminais garantistas, com aplicação do direito penal mínimo, fundado na estrita legalidade, analisado em seu aspecto substancial e não meramente formal.

Palavras-chave: Garantismo penal; Políticas criminais; Violações aos direitos fundamentais do preso.

\begin{abstract}
The one that commits a criminal offense, after being processed and convicted to serve time, in a Democratic State based on the rule of law, respecting the constitutional principles, will only be deprived of the legal good liberty. There is no legitimacy in and it hurts the finalty of the punishment application to disrespect the fundamental rights of the prisoner. Although, the brazilian prison system repeatedly disrespect fundamental rights, beyond deprivation of liberty. This work proposes analyzing the occurrence and the consequences of vio-lating the fundamental rights of prisoners in regard to the Criminal Garantism theory, the perspective developed by the preceptor Luigi Ferrajoli, proposing that the State is responsible for developing criminal garantist politics, applying the minimum criminal law, based on strict legality, analyzed in its substantial aspect and not in its merely formal one.
\end{abstract}

Keywords: Criminal garantism; Criminal politics; Disrespect of fundamental rights to prisoners. 


\section{SUMÁRIO}

INTRODUÇÃO. 1 JUSTIFICAÇÃO GARANTISTA PARA APLICAÇÃO DA PENA EM UM ESTADO DEMOCRÁTICO DE DIREITO; 2 A TEORIA DO GARANTISMO PENAL E SUA APLICAÇÃO PRÁTICA NO ORDENAMENTO JURÍDICO BRASILEIRO; 3 A POLÍTICA CRIMINAL EM UMA PERSPECTIVA GARANTISTA; 4 CONCLUSÃO; REFERÊNCIAS.

\section{INTRODUÇÃO}

O objetivo do presente trabalho é analisar a ineficiência da atuação do Estado à luz da teoria garantista na perspectiva desenvolvida por Luigi Ferrajoli na obra Direito e Razão: Teoria do Garantismo Penal reputada como a mais conhecida e divulgada doutrina contemporânea do garantismo jurídico, especialmente na arbitrariedade com a qual os direitos fundamentais dos presos são sistematicamente violados nos presídios brasileiros, desta forma, buscaremos analisar a aplicação dos ideais da teoria garantista além da norma penal e processual, precisamente durante a execução da pena.

Inicialmente, abordaremos a justificação da aplicação da pena e do exercício do direito de punir, considerando que o jus puniendi é atribuído de forma exclusiva ao Estado, cuja pretensão punitiva nasce a partir do cometimento de um crime, há necessidade que o Estado atue com respeito aos direitos e garantias fundamentais ao aplicar a sanção penal, reduzindo os danos causados pela execução da pena, haja vista que a violação aos direitos fundamentais do recluso afronta os princípios constitucionais e o Estado Democrático de Direito.

Em seguida, o presente trabalho objetiva relacionar a teoria do garantismo penal com as bases elementares do sistema penal brasileiro, realizando um estudo do conceito do garantismo penal e verificando em quais aspectos o Brasil deixa de aplicá-lo, considerando a legislação penal, processual penal, e a Lei $n^{\circ}$ 7.210/84, que regula a execução penal. Será demonstrado que embora tenhamos um sistema legal formalmente garantista, a operacionalização prática do sistema penal deixa de garantir substancialmente a aplicação das leis, violando os direitos fundamentais dos presos de forma sistemática.

Por fim, discutiremos a importância de políticas públicas criminais que efetivamente garantam os direitos fundamentais dos presos, tendo em vista a necessidade de repensar o estabelecimento prisional, ante a falta de vagas e o ambiente insalubre e indigno que aumenta os danos causados ao recluso, fortalecendo-se a elaboração de políticas públicas fundamentadas no direito penal mínimo, reservando-se a aplicação de penas privativas de liberdade aos delitos 
mais graves, com enfoque na ampliação da utilização de penas alternativas a prisão e aproveitamento dos dogmas trazidos pela Justiça Restaurativa.

\section{JUSTIFICAÇÃO GARANTISTA PARA APLICAÇÃO DA PENA EM UM ESTADO DEMOCRÁTICO DE DIREITO}

O direito de punir, jus puniendi, é exercido de forma privativa pelo Estado, portanto, quando um indivíduo viola a lei penal, lesando ou expondo a perigo de lesão bens jurídicos relevantes, tipificados como crimes, nasce a pretensão punitiva estatal, sendo certo que a consequência jurídica do delito é a aplicação da sanção penal, após a demonstração da violação da lei penal, através do devido processo legal, com respeito a todos os princípios constitucionais pertinentes, tais como ampla defesa e contraditório.

Na lição de Fernando da Costa Tourinho Filho:

O jus puniendi pertence, pois, ao Estado, como uma das expressões mais características de sua soberania. [...] Quando o Estado, por meio do Poder Legislativo, elabora leis penais, cominando sanções àqueles que vierem a transgredir o mandamento proibitivo que se contém na norma penal, surge para ele o jus puniendi num plano abstrato e, para o particular, o dever de abster-se de realizar a conduta punível. [...] Desse modo, o Estado pode exigir que o interesse do autor da conduta punível em conservar a sua liberdade se subordine ao seu, que é o de restringir o jus libertatis com a inflição da pena. ${ }^{1}$

A sanção penal divide-se em pena, cujas espécies são privativa de liberdade, restritivas de direitos e multa (aplicada aos imputáveis, assim considerados os maiores de dezoito anos com plena capacidade mental, possibilitando-lhes entender o caráter criminoso do fato e determinarse de acordo esse entendimento) e medida de segurança, consistente em internação em hospital psiquiátrico ou tratamento ambulatorial (aplicada aos inimputáveis, que são aqueles portadores de doença mental que os tornam incapazes de entender o caráter criminoso e autodeterminarem-se no momento do crime).

Destacamos que a Lei de Execução Penal incorporou dogmas trazidos pelo movimento da Nova Defesa Social, atribuindo à pena, três finalidades: a) punição, visando retribuir ao indivíduo com o mal da pena o mal do injusto penal praticado; b) prevenção, buscando inibir a ocorrência de novos delitos, seja pela prevenção especial, retirando o criminoso do meio social, seja pela prevenção geral, com a intimidação dos demais membros da sociedade, que não

${ }^{1}$ TOURINHO FILHO, Fernando da Costa. Processo Penal. Vol. 1. 34 ed. São Paulo: Saraiva, 2012, p. 27. 
optaram pela delinquência, sob ameaça de sofrerem o mal da pena; c) ressocialização, objetivando a recuperação do criminoso, para que após a punição sofrida não volte a cometer outros crimes.

Salo de Carvalho, em relação à incorporação das leis penais brasileiras, da ideologia trazida pelo movimento da Nova Defesa Social, afirma que:

Se os institutos advindos da projeção do paradigma etiológico pelo movimento reformista da Nova Defesa Social não foram adotados pela reforma penal brasileira de 1984 de forma plena, segundo o projeto transnacional do movimento, algumas premissas foram enraizadas no sistema de execução penal nacional e sustentam, até os dias atuais, um modelo penalógico aparentemente híbrido, mas que consolida empírica e processualmente a ideologia do tratamento.

[...] categorias como periculosidade, reeducação, personalidade do agente, prevenção da reincidência e medidas de segurança extrapenais compõem este universo projetivo de prevenção especial devido ao deslocamento sutil e eficaz da teoria defensivista. ${ }^{2}$

Sob a perspectiva garantista a execução da pena não legitima a falaciosa busca da cura ou reeducação do criminoso, haja vista que ao Estado não seria atribuída à legitimidade para reeducar aquele que comete crime, posto que assim agindo, haveria legitimação do desrespeito à integridade moral e dignidade humana, não permitindo que o indivíduo tenha liberdade para ser quem ele é, opondo-se, portanto, ao movimento da Nova Defesa Social.

Considerar a pena como instrumento curativo ou reeducativo, pressupondo ser o delito uma patologia individual ou social, pressupõe aproximação dos conceitos de natureza (e/ou moral) com direito. As concepções penalógicas nas quais há simetria entre direito e natureza (teorias de Defesa Social) e direito e moral (teorias da emenda) são as mais antiliberais e antigarantistas teorias já concebidas, justificando modelos maximalistas e substancialistas. ${ }^{3}$

Atribuir à pena uma finalidade reeducadora e ressocializadora, segundo Ferrajoli, é tornar a sua execução mais aflitiva, desrespeitando os direitos fundamentais do criminoso e deslegitimando o direito de punir do Estado, aumentando os danos e estigmas causados pelo cumprimento da pena privativa de liberdade, somente justificável a partir do ideal de minimização dos danos causados àquele ao qual a pena foi imposta.

[...] conferindo ao direito penal o objetivo de minimizar as lesões (ou exponenciar a tutela), quer dos direitos dos desviantes, quer dos direitos dos não

${ }^{2}$ CARVALHO, Salo de. Pena e Garantias. $3^{\text {a }}$ Ed. Rio de Janeiro: Lumen Juris, 2008, p. 136.

${ }^{3}$ Ibid, 2008, p. 139. 
desviantes, o nosso esquema preclui autojustificações apriorísticas de modelos de direito penal máximo, consentindo somente justificações, a posteriori, de modelos de direito penal mínimo. Em particular, ele reconhece que a pena, em razão do seu caráter aflitivo e coercitivo, é, de qualquer forma, um mal que de nada serve envolver com o manto de uma finalidade filantrópica de tipo reeducativo ou ressocializante, e, de fato, ainda mais aflitivo. Entretanto, ainda que seja um mal, a pena é de qualquer forma justificável se (e somente se) o condenado dela extrai o benefício de ser, por seu intermédio, poupado de punições informais imprevisíveis, incontroladas e desproporcionais. ${ }^{4}$

A compreensão da justificação da execução da pena sob a ótica do garantismo penal depende da análise dos limites conferidos ao direito de punir do Estado, advindo do pacto social.

Na lição de Salo de Carvalho:

A passagem do estado de natureza para o estado civil representaria a transferência do poder privado ao poder público, designando a saída da barbárie e a opção pela civilidade, visto que o gozo incontrolado dos direitos e privilégios da lei da natureza acabaria por lesar os direitos do outro. Na renúncia ao exercício das próprias razões, e na constituição do Estado (civil), exsurge o pensamento iluminista consagrado no consenso, sepultando o velho paradigma do medievo.

O que diferencia substancialmente os dois estados é o (re)conhecimento da Lei, livremente consentida e tutelada por um sujeito que, ao abdicar das paixões, torna-se racional na resolução do conflito.

O que funda o status civitas é a renúncia do gozo ilimitado, a imposição de limites e a sanção da violência ao outro. 0 custo da renúncia em fruir e dispor ilimitadamente seria minimizado/compensado pela promessa de segurança.

Consagra-se, portanto, um Estado com o fim precípuo de assegurar a preservação da dignidade e das propriedades do homem contra os poderes passionais ilimitados. O Estado, racionalizador imparcial do desejo de vendeta (direito natural do homem quando lesado em seus direitos), apropria-se do poder de autotutela, tomando para si o direito de punir, com escopo de assegurar a proporcionalidade na resolução da contenda. ${ }^{5}$

O pacto social proporciona direitos e deveres recíprocos entre o Estado e os cidadãos. 0 homem cede parcela de sua liberdade ao Estado, como recompensa usufrui da segurança da vida em sociedade, devendo submeter-se às leis estatais. Desta forma, o Estado nasce e se legitima devido à necessidade de segurança dos indivíduos, por meio da qual, adquirem a tranquilidade necessária para desenvolverem suas potencialidades.

"Foi a necessidade, portanto", escreve Beccaria, "que forçou os homens a cederem parte da própria liberdade; por consequência, ele está certo de que cada um deles não quis depositar, na esfera pública, nada além da mínima

\footnotetext{
${ }^{4}$ FERRAJOLI, Luigi. Direito e Razão: Teoria do Garantismo Penal. Tradução de Ana Paula Somer Sica, Fauzi Hassan Choukr, Juarez Tavares, Luiz Flávio Gomes. $3^{\text {a }}$ ed. São Paulo: Revista dos Tribunais, 2002. p. 272. ${ }^{5}$ CARVALHO, Salo de. Pena e Garantias. $3^{a}$ Ed. Rio de Janeiro: Lumen Juris, 2008, p. 30-32.
} 
porção possível, bastante para induzir os outros a defendê-lo. 0 conjunto destas mínimas porções possíveis forma o direito de punir; tudo mais é abuso e não justiça, é fato mas não mais direito". ${ }^{6}$

O direito de punir não é mais exercido de forma privada pelos indivíduos através da autotutela, sendo transferido ao Estado, que, contudo, não o exerce de forma ilimitada, havendo restrição por meio do respeito às leis.

O Estado, racionalizador imparcial do desejo de vendeta (direito natural do homem quando lesado em seus direitos), apropria-se do poder de autotutela, tomando para si o direito de punir, com escopo de assegurar a proporcionalidade na resolução da contenda.

A perspectiva contratualista, portanto, fornece o solo fértil ao pensamento garantista, visto que assentada na limitação dos poderes pela legalidade: a tutela dos direitos do homem contra os poderes privados com a negação do estado de natureza e a opção pelo estado civil; a proteção dos direitos do cidadão contra o abuso dos poderes públicos, desde uma perspectiva limitadora do exercício da violência estatal. ${ }^{7}$

Em um Estado Democrático de Direito, tal como determina nossa Constituição Federal em seu artigo $1^{\circ}$, deve existir respeito aos direitos e garantias fundamentais. Não basta apenas haver previsão legal a respeito de direitos fundamentais, mas sim que o Estado efetive mecanismos de garantias aos direitos fundamentais reconhecidos, legitimando a execução do poder estatal em face ao cidadão.

[...] sendo a democracia modo de exercício do poder, é processo, o que significa que a técnica pela qual o poder, advindo da vontade popular, é exercido, deve coadunar-se aos procedimentos preestabelecidos mediante leis elaboradas por representantes eleitos, isto é, deve obedecer ao princípio da legalidade na execução do poder, pelo que o ato de autoridade tem validade segundo sua conformação legal, o que liga toda a execução da lei à origem, que é a vontade popular. (...) Enfim, é o Estado Democrático de Direito que se apresenta como organização político-estatal possibilitadora de uma legalidade legítima, que se funda nos direitos fundamentais criados soberanamente pelo próprio povo, destinatário e coautor da ordem jurídica, É nesse Estado que a autonomia política atua contra a arbitrariedade de um poder mediante sua domesticação pelo jurídico. ${ }^{8}$

Segundo Marco Aurélio Souza da Silva:

\footnotetext{
${ }^{6}$ Ibid, 2002, p. 212.

${ }^{7}$ Ibid, 2008, p. 32.

${ }^{8}$ DIAZ, Elias. Legalidad - legitimidade en el Socialismo Democrático. Espanha: Editorial Civitas S.A., 1978, p. 120.
} 
Em um Estado Constitucional e Democrático de Direito, a observação dos direitos fundamentais constitui um dever dos agentes públicos e das instituições fiscalizadoras, que também têm contribuído significativamente com a omissão, o descaso e a ineficiência de suas atuações. ${ }^{9}$

$\mathrm{Na}$ concepção de Estado de Direito, trazida por Luigi Ferrajoli como sinônimo de garantismo, resta claro a necessidade ao respeito das leis vigentes, bem como dos direitos fundamentais.

\begin{abstract}
"Estado de direito" é um daqueles conceitos amplos e genéricos que tem múltiplas e variadas ascendências na história do pensamento político: a ideia, que remonta a Platão e Aristóteles, do "governo das leis" contraposto ao "governo dos homens", a doutrina medieval da fundação jurídica da soberania, o pensamento político liberal sobre os limites da atividade do Estado e sobre o Estado mínimo, a doutrina jusnaturalista do respeito às liberdades fundamentais por parte do direito positivo, o constitucionalismo inglês e norte-americano, a tese da separação dos poderes, a teoria jurídica do Estado elaborada pela ciência juspublicista alemã do século passado e pelo normativismo kelseniano. Segundo uma distinção sugerida por Norberto Bobbio, isto pode querer dizer duas coisas: governo sub lege ou submetido às leis, ou governo per leges ou mediante leis gerais e abstratas.

[...]

O termo "estado de direito" é aqui empregado no segundo destes dois significados [em sentido forte, estrito ou substancial]; e neste sentido é sinônimo de "garantismo". Designa, por esse motivo, não simplesmente um "Estado legal" ou "regulado pelas leis", mas um modelo de Estado nascido com as modernas Constituições e caracterizado: a) no plano formal, pelo princípio da legalidade, por força do qual todo o poder público - legislativo, judiciário e administrativo está subordinado às leis gerais e abstratas que lhes disciplinam as formas de exercício e cuja observância é submetida a controle de legitimidade por parte dos juízes delas separados e independentes [...]. b) no plano substancial da funcionalização de todos os poderes do Estado à garantia dos direitos fundamentais dos cidadãos, por meio da incorporação limitadora em sua Constituição dos deveres públicos correspondentes, isto é, das vedações legais de lesão aos direitos de liberdade e das obrigações de satisfação dos direitos sociais, bem como dos correlativos poderes dos cidadãos de ativarem a tutela judiciária. $^{10}$
\end{abstract}

A aplicação da pena, para não ser forma de exercício de vingança e violência contra o cidadão, deve ser pautada pela legalidade e respeito aos direitos individuais, visando à

\footnotetext{
${ }^{9}$ SILVA, Marco Aurélio Souza da. POLÍTICA PÚBLICA CARCERÁRIA: UMA INSTITUCIONALIZADA VIOLAÇÃO DE DIREITOS FUNDAMENTAIS IMPULSIONADA PELA CRIMINALIZAÇÃO DAS DROGAS. Revista Eletrônica do Curso de Direito da UFSM. Rio Grande do Sul, v. 9, n. 2, p. 233- 262. Disponível em: <http://cascavel.ufsm.br/revistas/ojs2.2.2/index.php/revistadireito/article/view/13018/pdf\#.Vnb2bF51 WRg> Acesso em: 20 set. 2015, p. 234.

${ }^{10}$ Ibid, 2002, p. 687-688.
} 
prevenção da ocorrência dos delitos e consequente prevenção da necessidade de aplicação dos castigos, protegendo à sociedade e os indivíduos nela inseridos.

Prevenção dos delitos e prevenção dos castigos conformaria o modelo garantista do direito penal como negação da guerra e proteção do mais fraco. A centralidade da pessoa em seus direitos fundamentais é recuperada pela dupla função penalógica, legitimando sua 'necessidade política' e os critérios de limitação dos delitos e dos castigos. ${ }^{11}$

A investigação da legitimidade da aplicação da pena sob a perspectiva garantista retira do Estado Democrático de Direito o poder de punir de forma desmedida, exercido como uma nefasta forma de vingança pública, bem como não legitima a aplicação da pena com a finalidade de transformar a personalidade do indivíduo, tolhendo sua liberdade de consciência e vontade para autodeterminar-se.

A utilização do aparelho penal de controle social para determinar (lei penal), valorar (processo) e transformar (pena) personalidades consideradas perigosas (outsiders) conforma um projeto político-criminal antidemocrático, tendente à profilaxia social, típico de sistemas totalitários. ${ }^{12}$

Um sistema de execução penal efetivamente garantista deverá determinar-se pela redução dos danos causados pela aplicação da pena privativa de liberdade, visando preservar os demais direitos fundamentais e especialmente a dignidade daquele que cometeu uma conduta criminosa.

Todas as pessoas, independente de terem incorrido em sanção penal, preservam e devem ter asseguradas condições de dignidade. 0 garantismo penal é, pois, um instrumento de salvaguarda de todos, desviantes ou não, visto que, em sendo estereótipo de racionalidade, tem como escopo minimizar a(s) violência(s) (públicas e/ou privadas).

[...]

Reduzir dor e sofrimento (redução de danos) seria o único motivo de justificação da pena nas atuais condições em que é exercida, principalmente nos países periféricos. $^{13}$

Ferrajoli ao discorrer sobre a justificação para aplicação da pena privativa de liberdade afirma que:

\footnotetext{
${ }^{11}$ Ibid, 2008, p. 148.

12 Ibid, 2008, p. 138.

${ }^{13}$ Ibid, 2008, p. 94 e 142.
} 
Excluída qualquer finalidade de emenda ou disciplinatória, a única coisa que se pode e se deve pretender da pena é que, como escreveu Francesco Carrara, "não perverta o réu": quer dizer, que não reeduque, mas também que não deseduque, que não tenha uma função corretiva, mas tampouco uma função corruptora; que não pretenda fazer o réu melhor, mas que tampouco o torne pior. Mas para tal fim não há necessidade de atividades específicas diferenciadas e personalizadas. E necessário, sobretudo, que as condições de vida dentro da prisão sejam para todos as mais humanas e as menos aflitivas possíveis; que em todas as instituições penitenciárias esteja previsto o trabalho - não obrigatório, senão facultativo - juntamente com o maior número possível de atividades coletivas, de tipo recreativo e cultural; que na vida carcerária se abram e desenvolvam espaços de liberdade e de sociabilidade mediante a mais ampla garantia de todos os direitos fundamentais da pessoa; que, por fim, seja promovida a abertura da prisão - os colóquios, encontros conjugais, permissões, licenças etc. - não mediante a distribuição de prêmios e privilégios, senão com a previsão de direitos iguais para todos. ${ }^{14}$

Luiz Fábio Silva Paiva afirma que "a consolidação da democracia no Brasil tem enfrentado uma série de problemas relacionados ao reconhecimento de direitos estabelecidos em leis, mas não cumpridos na prática." ${ }^{15}$

O desrespeito aos direitos fundamentais é causa de insatisfações e dissenso, vez que, não recebendo qualquer vantagem por abrir mão de parte da sua liberdade em prol da coletividade, o indivíduo não enxerga razões para continuar obedecendo ao pacto social. ${ }^{16}$

A execução da pena no Brasil, especialmente no que tange as penas privativas de liberdade, objeto do presente estudo, enfrenta grave problema, que culmina em inúmeras violações aos direitos fundamentais daqueles que estão encarcerados nos presídios brasileiros, caracterizando a ineficiência do Estado em garantir as condições mínimas de dignidade necessárias ao cumprimento da pena.

Contrariamente, o que acontece é que o sistema carcerário é tão precário (presos doentes, sem assistência médica, hospitalar, péssima alimentação, sem higiene alguma, em locais insalubres, dormindo mal, sem assistência ou defesa judiciária, entre outros), que conduz a revolta dos apenados, bem como, a

\footnotetext{
${ }^{14}$ Ibid, 2002, p. 319.

15 PAIVA, Luiz Fábio Silva Paiva. À Espera de Respostas: Reflexões sobre o Trabalho da Justiça Criminal. Revista Dilemas. Rio de Janeiro, n. 4, p. 49 - 82, 2009. Disponível em: <http://revistadil.dominiotemporario.com/doc/Dilemas4Art2.pdf> Acesso em: 17 set. 2015, p. 49.

${ }^{16}$ ARANÃO, Adriano. Estado Democrático de Direito, Criminalidade e Violência: O Desrespeito aos Direitos Fundamentais e o Papel da Educação. Revista Argumenta. Jacarezinho, n. 08, p. 215-231, 2008. Disponível em: <http://seer.uenp.edu.br/index.php/argumenta/article/view/105/105> Acesso em: 17 set.e 2015, p. 219.
} 

periculosidade. ${ }^{17}$

Não restam dúvidas, portanto, que o Estado exerce o direito de punir, e para tanto, por meio do Poder Legislativo, em obediência ao princípio da legalidade, elabora as leis penais, processuais penais e de execução penal, e por meio do Poder Judiciário, através do devido processo legal, concretiza a aplicação da sanção penal, porém, durante a execução da pena, não poderá o Poder Executivo agir com desprezo aos direitos e garantias fundamentais dos reclusos, sob pena de ofensa a Constituição Federal, bem como a Teoria do Garantismo Penal.

\section{A TEORIA DO GARANTISMO PENAL E SUA APLICAÇÃO PRÁTICA NO ORDENAMENTO JURÍDICO BRASILEIRO}

O autor italiano Luigi Ferrajoli desenvolveu na obra Direito e Razão: Teoria do Garantismo Penal as bases para a definição do termo "garantismo" abrangendo três concepções distintas, quais sejam: a) um modelo normativo de direito; b) uma teoria jurídica onde vigência e validade apresentam-se como categorias jurídicas diversas; c) uma filosofia política que exige do Direito e do Estado justificação externa.

Nos dizeres de Ferrajoli:

Segundo um primeiro significado, "garantismo" designa um modelo normativo de direito: precisamente, no que diz respeito ao direito penal, o modelo de "estrita legalidade" SG, próprio do Estado de direito, que sob o plano epistemológico se caracteriza como um sistema cognitivo ou de poder mínimo, sob o plano político se caracteriza como uma técnica de tutela idônea a minimizar a violência e a maximizar a liberdade e, sob o plano jurídico, como um sistema de vínculos impostos à função punitiva do estado em garantia dos direitos dos cidadãos.

[...]

Em um segundo significado, "garantismo" designa uma teoria jurídica da "validade" e da "efetividade" como categorias distintas não só entre si mas, também, pela "existência" ou "vigor" das normas. Neste sentido, a palavra garantismo exprime uma aproximação teórica que mantém separados o "ser" e o "dever ser" no direito; e, aliás, põe como questão teórica central, a divergência existente nos ordenamentos complexos entre modelos normativos (tendentemente garantistas) e práticas operacionais (tendentemente antigarantistas), interpretando-a com a antinomia - dentro de certos limites

17 MARCON, Danieli Cristina. A democracia e a Realidade da Execução Penal Brasileira. Revista Argumenta. Jacarezinho, n. 10, p. 199-214, $2009 . \quad$ Disponível em: <http://seer.uenp.edu.br/index.php/argumenta/article/view/134/134> Acesso em: 17 set. 2015 , p. 201. 
fisiológica e fora destes patológica - que subsiste entre validade (e não efetividade) dos primeiros e efetividade (e invalidade) das segundas.

[...]

Segundo um terceiro significado, por fim, "garantismo" designa uma filosofia política que requer do direito e do Estado o ônus da justificação externa com base nos bens e nos interesses dos quais a tutela ou a garantia constituem a finalidade. Neste último sentido o garantismo pressupõe a doutrina laica da separação entre direito e moral, entre validade e justiça, entre ponto de vista interno e ponto de vista externo na valoração do ordenamento, ou mesmo entre o "ser" e o "dever ser" do direito. E equivale à assunção, para os fins da legitimação e da perda da legitimação ético-política do direito e do Estado, do ponto de vista exclusivamente externo. ${ }^{18}$

Feitas essas considerações iniciais sobre o termo "garantismo" passaremos a analisar em quais aspectos o sistema prisional brasileiro viola os direitos fundamentais, deixando de aplicar as bases nas quais se funda a teoria do garantismo penal.

Considerando que o garantismo penal abrange um modelo normativo de direito, ou seja, o exercício do jus puniendi pelo Estado somente poderá ocorrer com fundamento no princípio da estrita legalidade, no que se refere à execução da pena, podemos afirmar que nosso ordenamento jurídico dispõe de um modelo normativo de direito.

A Constituição Federal e a Lei $n^{\circ}$ 7.210/84 - Lei de Execução Penal (LEP) asseguram aos presos o exercício de todos os direitos não atingidos pela perda da liberdade, incluindo o respeito à integridade física e moral, visando garantir a dignidade do preso, bem como diversos direitos voltados à busca pela ressocialização.

A Lei de Execução Penal, em seus dispositivos legais, garante ao preso assistência material, à saúde, jurídica, educacional, social, religiosa, bem como assistência ao egresso. Prevê em seu artigo 28 que o trabalho do condenado, é um dever social e condição de dignidade humana, tendo finalidade educativa e produtiva.

O capítulo IV do título II da LEP trata de forma minuciosa dos deveres, dos direitos e da disciplina carcerária.

Por sua vez, o capítulo I do título IV dispõe a respeito das condições que estabelecimentos penais devem oferecer aos reclusos, prevendo as regras de funcionamento e acomodação nas penitenciárias, (destinadas àqueles que cumprem pena privativa de liberdade em regime fechado), nas colônias penais agrícolas, industriais ou similares (destinadas àqueles

${ }^{18} \mathrm{Ibid}, 2002$, p. $685-685$. 
que cumprem pena privativa de liberdade em regime semiaberto) e nas casas do albergado (destinadas àqueles que cumprem pena privativa de liberdade em regime aberto).

$\mathrm{O}$ título $\mathrm{V}$ da LEP contém as regras legais pertinentes à forma de execução das penas, regulamentando-se os benefícios a serem concedidos durante a execução penal, especialmente visando à integração social do recluso e consequentemente sua ressocialização, tais como as autorizações de saída (permissão de saída e saída temporária), remição penal, livramento condicional, além da existência da progressão de regime, prevista no Código Penal e na Lei dos Crimes Hediondos.

Portanto, a Lei de Execuções Penais contempla dispositivos legais modernos e que se coadunam com a teoria do garantismo penal, assegurando um sistema normativo penal racional, legítimo e justo para a execução da pena privativa de liberdade, o grande problema é encontrado no segundo significado do termo garantismo desenvolvido por Luigi Ferrajoli, haja vista que há uma enorme discrepância entre o sistema legal e a sua operacionalização prática.

Abordando a teoria do garantismo penal sob a ótica do "ser" e do "dever ser" ou em termos menos abstratos, sobre como as coisas como são e as coisas como devem ser não há dúvidas que as normas que regulamentam a execução penal no Brasil, embora possuam legitimidade e validade em confronto com a Constituição Federal e o Estado Democrático de Direito, posto que respeitam os direitos e garantias fundamentais do recluso, infelizmente não são efetivas, fato que impede nosso sistema prisional atuar de forma garantista, legítima e justa.

Conforme sustenta Ferrajoli:

Tratando-se de um modelo limite, dever-se-á, por outro lado, falar muito mais que de sistemas garantistas ou antigarantistas tout cort, de graus de garantismo; e, ademais, distinguir sempre entre o modelo constitucionalizo efetivo funcionamento do sistema. Diremos, por exemplo, que o grau de garantismo do sistema penal italiano é decididamente elevado caso se considerem os seus princípios constitucionais, enquanto é posto em níveis baixíssimos, caso se considere a sua prática efetiva. E mensuraremos a adequação de um sistema constitucional, sobretudo pelos mecanismos de invalidação e de reparações idôneos, de modo geral, a assegurar efetividade aos direitos normativamente proclamados: uma Constituição pode ser muito avançada em vista dos princípios e direitos sancionados e não passar de um pedaço de papel, caso haja defeitos de técnicas coercitivas - ou seja, de garantias - que propiciem o controle e a neutralização do poder e do direito ilegítimo. ${ }^{19}$

${ }^{19}$ Ibid, 2002, p. 684. 
A falta de efetividade em relação à aplicação da legislação em vigor sobre as regras da execução penal permite afirmarmos que nosso sistema prisional, possui um baixíssimo grau garantista, não "passando de um pedaço de papel”, como bem define Ferrajoli.

Para validade das normas penais, segundo a concepção garantista desenvolvida por Luigi Ferrajoli, não basta simplesmente estar em vigor, ou seja, satisfazer a validade formal, mas sim deverá ser substancialmente válida, ou seja, respeitar aos fundamentos constitucionais, especialmente efetivando os direitos fundamentais.

Para que uma norma exista ou esteja em vigor, é suficiente que satisfaça as condições de validade formal, as quais resguardam as formas e os procedimentos do ato normativo, bem como a competência do órgão que a emana. Para que seja válida, é necessário que satisfaça ainda as condições de validade substancial, as quais resguardam o seu conteúdo, ou seja, seu significado. Sejam as condições formais suficientes para que uma norma esteja vigente, sejam substanciais necessárias para que esteja válida, estão estabelecidas pelas normas jurídicas que thes disciplinam a produção em nível normativo superior. ${ }^{20}$

0 mais estarrecedor é percebemos que o antagonismo entre a validade formal e substancial das normas penais brasileiras, é uma constante violação aos direitos fundamentais ao longo da história do sistema prisional, tal como se comprova pela afirmação extraída da obra Comentários ao Código Penal, de Nelson Hungria, datada de 1959:

Infelizmente o nosso sistema de medida de segurança não passou ainda (...) de legislação de fachada. À parte dos superlotados manicômios judiciários, na sua maioria, instalados no tempo do código anterior, inexiste qualquer dos estabelecimentos reclamados pela nova diretriz de prevenção contra a delinquência. ${ }^{21}$

Segregar do convívio social, por um determinado período de tempo, aqueles que cometem delitos, parece realmente, que é a única preocupação do Estado, da mesma forma que o era em tempos medievais, sem qualquer preocupação com o respeito aos direitos e garantias que a própria legislação estatal consagra.

[...] Hoje em dia, aparentemente, continua sendo esta privação da liberdade, a única pena que se impõe aos delinquentes, mas de fato não é assim. Ao enviá-los às nossas prisões, na realidade se lhes está submetendo a penas corporais tão duras e adjetas como as medievais. ${ }^{22}$

\footnotetext{
${ }^{20}$ Ibid, 2002, p. 701.

${ }^{21}$ HUNGRIA, Nelson. Comentários ao Código Penal. Rio de Janeiro: Forense, 1959. p. 717-718.

${ }^{22}$ GOMES, Luiz Flávio; MOLINA, Antonio Garcia Plabos de. Criminologia. São Paulo: Revista dos Tribunais, 2000, p. 488.
} 
A atuação do Estado no sistema prisional, ignorando a validade da própria legislação em vigor, originada de forma democrática pelo Poder Legislativo, não difere em nada dos cidadãos que agem em desacordo com a legislação e, portanto, cometem delitos.

O Estado de direito deve combater o delito seguindo regras morais escrupulosas, sob pena de igualar-se aos delinquentes e de perder toda a autoridade e credibilidade. E as garantias que a Constituição assegura ao acusado não são simplesmente postas como tutela de seus direitos individuais, mas são, antes de mais nada, garantias do justo processo, assegurando o interesse geral à regularidade do procedimento e à justiça das decisões. ${ }^{23}$

O fundamento de validade do próprio direito penal é a defesa dos bens jurídicos relevantes, visando com que, através do devido processo legal e respeito aos demais princípios constitucionais, como ampla defesa, contraditório, presunção da inocência, aquele que cometeu determinada conduta prevista em lei como criminosa seja punido, com a finalidade de restabelecer a paz social. Contudo, o Estado ao negar efetividade às normas que asseguram os direitos fundamentais dos reclusos, quebra a expectativa da sociedade em restabelecer a paz.

Segundo sustenta Sérgio Cademartori, para aplicação da teoria garantista é necessário "um Estado minimizador das restrições das liberdades dos cidadãos dentro de um Estado Social maximizador das expectativas sociais, com correlatos deveres, do próprio Estado, de satisfazer tais necessidades". ${ }^{24}$

Não vislumbramos qualquer racionalidade e cumprimento das expectativas sociais, em um sistema prisional que descumpre a finalidade do próprio direito penal, não restituindo a paz social, mas sim gerando mais revoltas, tratamento degradante, impossibilidade de ressocialização e aumento da reincidência criminosa.

Os objetivos do sistema penal não estão sendo alcançados em todo mundo, apesar dos avanços tecnológicos mais sofisticados. A administração do regime penitenciário, para a execução da pena privativa de liberdade (prisão), desviasse cada vez mais das metas idealizadas. Assim, apesar das legislações estabelecerem propostas de reabilitação do preso, não passam elas, geralmente, de mitos que compõem a enorme lista de declarações retóricas, sem muito sentido de eficácia. Pelo contrário, tais ficções acabam, devido a sua inaplicabilidade prática, por produzir os fenômenos da estigmatização carcerária

\footnotetext{
${ }^{23}$ GRINOVER, Ada Pellegrini. O Processo Constitucional em Marcha. São Paulo: Max Limonad, 1985. p. 48.

${ }^{24}$ CADEMARTORI, Sérgio. Estado de Direito e Legitimidade - Uma Abordagem Garantista. Porto Alegre: Livraria do Advogado, 1999, p. 161.
} 
e da reincidência que compõem o drama trágico e as consequências da vida na prisão. ${ }^{25}$

É imprescindível que o Estado, em uma perspectiva garantista, desenvolva políticas públicas criminais voltadas a validar substancialmente as normas penais e de execução penal, possibilitando que o sistema penal cumpra sua finalidade de promover a paz social, restabelecendo a ordem, causando o menor dano ao recluso, ao invés de segregar provisoriamente aqueles que cometem delitos, e posteriormente, ao final do cumprimento da pena, devolvê-los à sociedade, após vilipendiar direitos fundamentais, tratando-os de forma indigna, perpetuando a estigmatização e o ódio, cuja consequência não pode ser outra, senão a perpetuação da violência.

\section{A POLÍTICA CRIMINAL EM UMA PERSPECTIVA GARANTISTA}

Até este ponto, no desenvolvimento do presente trabalho, percebemos que as leis em vigência no ordenamento jurídico brasileiro, a luz da teoria garantista sob a perspectiva desenvolvida por Luigi Ferrajoli, possuem validade formal, mas não são válidas substancialmente, posto que a operacionalização prática do sistema penal desrespeita de forma sistemática os direitos fundamentais dos reclusos.

A violação aos direitos fundamentais dos reclusos desrespeita o pacto social, fazendo com que a pena cause danos ilegítimos, haja vista que não há respeito por parte do Estado, das próprias leis em vigor, destinadas à proteção dos direitos individuais dos presos, que privados da dignidade, retornam ao convívio social, após o cumprimento da pena, com mais estigma e revolta, devolvendo à sociedade a violência sofrida durante o período vivenciado no cárcere.

Para que as leis penais, processuais penais e principalmente relacionadas à execução penal possuam validade substancial, respeitando os direitos fundamentais do recluso, há necessidade de efetivas políticas criminais voltadas ao controle da violência e das condições indignas dos presídios brasileiros.

(...) a política criminal determina a missão, os conteúdos e o alcance dos institutos jurídico-penais, bem como a aplicação prática do direito penal aos casos concretos. São as opções da política criminal que decidem sobre a

${ }^{25}$ GIACÓIA, Gilberto; HAMMERSCHMIDT, Denise; FUENTES, Paola Oviedo. A Prisão e a Condição Humana do Recluso. Revista Argumenta. Jacarezinho, n. 15, p. 131-161, 2011. Disponível em: <http://seer.uenp.edu.br/index.php/argumenta/article/view/202/201> Acesso em: 18 set. 2015, p. 132. 
incriminação ou não de determinadas condutas, considerando-se a vantagem social da qualificação, bem como quem deve ser responsabilizado. ${ }^{26}$

É através da política criminal que se via assegurada a forma mais eficaz possível para que o Direito Penal cumprisse sua tarefa de proteção à sociedade, fixandose nas causas do delito, comprovando a eficácia das sanções empregadas pelo Direito Penal e ponderando limites até onde pode o legislador estender o Direito Penal, preservando o mais possível o âmbito de liberdade dos cidadãos. ${ }^{27}$

Sergio Salomão Shecaira afirma que a política criminal é a “disciplina que estuda as estratégias estatais para a atuação preventiva da criminalidade, e que tem por finalidade estabelecer a ponte eficaz entre a criminologia, enquanto ciência empírica, e o direito penal, enquanto ciência axiológica". ${ }^{28}$

Nilo Batista apresenta a política criminal da seguinte forma:

Do incessante processo de mudança social, dos resultados que apresentem novas ou antigas propostas do direito penal, das revelações empíricas propiciadas pelo desempenho das instituições que integram o sistema penal, dos avanços e descobertas da criminologia, surgem princípios e recomendações para a reforma ou transformação da legislação criminal e dos órgãos encarregados de sua aplicação. A esse conjunto de princípios e recomendações denomina-se política criminal. Segundo a atenção se concentre em cada etapa do sistema penal, poderemos falar em política de segurança pública (ênfase na instituição policial), política judiciaria (ênfase na instituição judicial) e política penitenciária (ênfase na instituição prisional), todas integrantes da política criminal. ${ }^{29}$

Neste trabalho, analisaremos as políticas públicas penitenciárias desenvolvidas pelo Estado, especialmente no que tange ao respeito aos direitos e garantias fundamentais dos reclusos como forma diminuição dos danos causados pela aplicação da pena e consequente diminuição do estigma do cumprimento da pena privativa de liberdade.

Inicialmente devemos esclarecer que a política criminal baseada na teoria garantista nos termos propostos por Luigi Ferrajoli, desde a produção legislativa deve preocupar-se em tornar o direito penal a ultima ratio, buscando uma intervenção estatal mínima, limitando o

\footnotetext{
${ }^{26}$ ROCHA, Fernando Antonio N. Galvão da. Responsabilidade Penal da Pessoa Jurídica. Revista de Direito Ambiental, São Paulo, v.7, n.27, jul./set., 2002, p. 78.

${ }^{27}$ GOMES, Décio Luiz Alonso. Política Criminal Brasileira e o Papel do Ministério Público. In: Ministério Público e Políticas Públicas, Rio de Janeiro: Lumem Juris, 2007, v.1, p. 24.

${ }^{28}$ SHECAIRA, Sérgio Salomão. Pena e Política Criminal: A Experiência Brasileira. In SHECAIRA, Sérgio Salomão; SÁ, Alvino Augusto de (Orgs.). Criminologia e os Problemas da Atualidade. São Paulo: Atlas, 2008, p. 325.

${ }^{29}$ BATISTA, Nilo. Introdução Crítica ao Direito Penal Brasileiro. 11. ed., Rio de Janeiro: Revan, 2007, p. 34.
} 
poder punitivo estatal e maximizando as garantias penais e processuais penais, somente aplicando-se sanções penais em casos graves e necessários, especialmente em se tratando de aplicação da prisão.

A teoria garantista na obra elaborada pelo Ferrajoli é baseada nos seguintes princípios que deverão orientar a intervenção estatal mínima, visando determinar um sistema normativo penal racional, legítimo e justo.

Denomino estes princípios, ademais das garantias, penais e processuais por eles expressas, respectivamente: 1) princípio da retributividade ou da consequencialidade da pena em relação ao delito; 2) princípio da legalidade, no sentido lato ou no sentido estrito; 3 ) princípio da necessidade ou da economia do direito penal; 4) princípio da lesividade ou da ofensividade do evento; 5) princípio da materialidade ou da exterioridade da ação; 6) princípio da culpabilidade ou da responsabilidade pessoal; 7) princípio da jurisdicionariedade, também no sentido lato ou no sentido estrito; 8) princípio acusatório ou da separação entre juiz e acusação; 9) princípio do ônus da prova ou da verificação; 10) princípio do contraditório ou da defesa, ou da falseabilidade. ${ }^{30}$

Desta forma, a política criminal garantista deverá ser voltada a intervenção do Estado em atenção ao princípio da necessidade ou da economia do direito penal, minimizando a repressão penal.

Conforme já ressaltamos no presente trabalho, nossa Constituição Federal possui viés garantista, haja vista que consagra os princípios propostos por Ferrajoli e prevê os direitos fundamentais aos reclusos, ocorre que nosso sistema prisional, possui um baixíssimo grau garantista, não “passando de um pedaço de papel”, na correta expressão de Ferrajoli. ${ }^{31}$

Infelizmente nossa Constituição já supera os 15 anos de vigência e continua sendo (no recorte anteriormente definido) uma ilustre desconhecida em muitas delegacias, foros e tribunais brasileiros, incluindo, obviamente, alguns péssimos exemplos dados pelo Superior Tribunal de Justiça e pelo Supremo Tribunal Federal. Diariamente nos deparamos, desde a tribuna, nas audiências, nas delegacias, com um certo desprezo quando é invocada a violação deste ou daquele dispositivo constitucional. Não raras vezes, presenciamos suspiros de enfado, de ironia até, quando citado o art. $5^{\circ}$ da Constituição. É impressionante como é comum ouvirmos comentários do estilo: lá vêm eles com o discurso da Constituição, invocando novamente os tais direitos fundamentais, vamos deixar a Constituição para lá...não é bem isso que ela quis dizer... ${ }^{32}$

\footnotetext{
${ }^{30}$ Ibid, 2002, p. 75.

31 Ibid, 2002, p. 684.

${ }^{32}$ LOPES JR., Aury. Introdução Crítica ao Processo Penal. Fundamentos da Instrumentalidade Garantista. $3^{\mathrm{a}}$ ed. Rio de Janeiro: Lumen Juris, 2005, p. 44.
} 
Não basta a produção legislativa, com a criação de leis penais formalmente garantistas, para resolver o problema da criminalidade, é necessário que o Estado estabeleça políticas públicas penitenciárias, que minimizem o dano causado pela pena, nos estritos limites da proteção e segurança social, permitindo com que as leis que regulam a execução penal sejam substancialmente cumpridas pelo Poder Público.

Há desrespeito sistemático do Estado aos direitos fundamentais e as previsões legais contidas na Lei $n^{\circ} 7210 / 84$, que regula a execução penal, como vimos no capítulo 2 do presente trabalho.

Sobre o sistema penitenciário brasileiro, sustenta Rogério Greco ao discorrer a respeito dos presos "que foram condenados ao cumprimento de uma pena privativa de liberdade são afetados, diariamente, em sua dignidade, enfrentando problemas como os da superlotação carcerária, espancamentos, ausência de programas de reabilitação etc". ${ }^{33}$

Não apenas durante o cumprimento da pena há desrespeito aos direitos e garantias fundamentais, mas conforme segue Rogério Greco, para aquele que cumpre a pena, ou seja, o egresso do sistema prisional "não existem programas governamentais para sua reinserção social, além do fato de a sociedade não perdoar aquele que já foi condenado por ter praticado uma infração penal". ${ }^{34}$

Notemos que o artigo 10 da Lei de Execução Penal prevê que "a assistência ao preso e ao internado é dever do Estado, objetivando prevenir o crime e orientar o retorno à convivência em sociedade", por sua vez em seu parágrafo único, há previsão da assistência ao egresso. Os incisos do mencionado artigo 10 da LEP determinam que a assistência a ser prestada ao recluso e ao egresso é material (alimentação, vestuário, instalações prisionais dignas), à saúde, jurídica, educacional (escolar e profissional), social (amparo ao recluso e egresso, visando o exercício da cidadania) e religiosa.

0 artigo 25 da LEP prevê que a assistência ao egresso consiste na orientação e apoio para reintegrá-lo à vida em liberdade e na concessão, se necessário, de alojamento e alimentação, em estabelecimento adequado, pelo prazo de 2 (dois) meses, cujo prazo poderá ser prorrogado uma única vez, comprovado, por declaração do assistente social, o empenho na obtenção de emprego. A realidade, contudo, é muito distante da previsão legal:

${ }^{33}$ GRECO, Rogério. Curso de Direito Penal. Vol. 1 Parte Geral. Rio de Janeiro: Impetus. 2012, p. 649.

${ }^{34}$ Ibid, 2012, p. 649. 
[...] os estabelecimentos carcerários do Brasil padecem de doenças que lembram os calabouços feudais. Seus prédios são tipicamente decrépitos e insalubres, com concreto desmoronando por toda parte, pintura descascando, encanamento deficiente e instalações elétricas defeituosas, com água de esgoto correndo pelo chão ou caindo pelas paredes - o fedor dos dejetos era tão forte na cadeia "modelo" de Lemos de Brito (Rio de Janeiro) na primavera de 2001 que um dos bens mais apreciados pelos presos era o desinfetante perfumado que borrifavam em suas celas na tentativa de combater a sufocante pestilência. A extrema ruína física e a grotesca superlotação criam condições de vida abomináveis e uma situação catastrófica em termos de higiene, diante da total falta de espaço, ar, luz, água e muitas vezes comida. ${ }^{35}$

De fato, como falar em respeito à integridade física e moral em prisões onde convivem pessoas sadias e doentes; onde o lixo e os dejetos humanos se acumulam a olhos vistos e as fossas abertas, nas ruas e galerias, exalam um odor insuportável; onde as celas individuais são desprovidas por vezes de instalações sanitárias, onde os alojamentos coletivos chegam a abrigar 30 ou 40 homens; onde permanecem sendo utilizadas, ao arrepio da proibição expressa da Lei $n^{\circ}$ $7.210 / 84$, as celas escuras, as de segurança, em que os presos são recolhidos por longos períodos sem banho de sol, sem direito a visita; onde a alimentação e o tratamento médico e odontológico são precários e a violência sexual atinge níveis desassossegantes? Como falar, insistimos, em integridade física e moral em prisões onde a oferta de trabalho inexiste ou é absolutamente insuficiente; onde presos são obrigados a assumirem a paternidade de crimes que não cometeram, por imposição dos mais fortes. ${ }^{36}$

Não há dúvidas, portanto, a respeito da necessidade do desenvolvimento de uma política pública destinada ao sistema penitenciário eficaz e garantista deverá atuar em três frentes: a) aplicação dos direitos e garantias fundamentais àqueles que estão cumprindo a pena privativa de liberdade, cumprindo-se de forma efetiva as regras previstas na Lei de Execução Penal; b) políticas públicas destinadas a conscientizar a população a respeito dos direitos fundamentais do preso e do egresso; c) políticas públicas inclusivas, visando reinserir o egresso na sociedade, visando à redução da reincidência criminosa, por meio da prevenção da violência, tais como políticas voltadas à capacitação profissional e educacional.

As políticas públicas deverão atuar sob as três vertentes acima expostas, buscando não apenas a melhoria nas condições de dignidade e salubridade dos estabelecimentos prisionais, mas igualmente objetivar a redução da estigmatização social trazida pelo cumprimento da pena, e a inclusão do egresso ao convívio social.

Em relação ao estigma sofrido por àquele que cumpre uma pena privativa de liberdade Ignacio Cano afirma que "muitas pessoas acreditam que o extermínio de criminosos e a negação

\footnotetext{
${ }^{35}$ WACQUANT, Löic. As Prisões da Miséria. Rio de Janeiro: Jorge Zahar, 2001, p. 208.

${ }^{36}$ LEAL, César Barros. Prisão: Crepúsculo de uma Era. Belo Horizonte: Del Rey, 2001, p. 89.
} 
de direitos aos mesmos não conflitam frontalmente com um talante respeitoso, já que, na sua percepção, os delinquentes não fazem parte do coletivo de cidadãos e não possuem direitos". ${ }^{37}$

É preciso deixar claro que a melhoria das condições de dignidade e salubridade dos presídios brasileiros passa pela conscientização do Estado e da sociedade a respeito da ineficácia da aplicação da pena privativa de liberdade de forma desmedida.

Segundo dados do Departamento Penitenciário Nacional - Depen no ano de 2014 a população carcerária no Brasil era de 607.731, e quantidade de vagas nos presídios era de 376.669, portanto, o déficit de vagas atingiu o patamar de 231.062, sendo certo que a diretora do Depen Valdirene Daufemback afirmou em audiência na Comissão de Direitos Humanos e Legislação Participativa (CDH) do Senado, que o "Brasil está numa marcha de encarceramento sem precedentes mundiais", caminhando-se para nos próximos 50 (cinquenta) anos tornar-se a maior população carcerária do mundo. ${ }^{38}$

Ora, as condições dos presídios brasileiros são extremamente indignas e violadoras dos direitos fundamentais dos presos, o aumento desmedido da população carcerária em nada contribuirá para a paz e segurança social, haja vista a limitação orçamentária para construção de mais estabelecimentos prisionais para acomodar os presos, bem como a ineficiência estatal na redução dos danos causados aos reclusos, que permanecem expostos a situações aflitivas, tais como ambientes insalubres e perniciosos.

Faz-se necessário, na esteira da teoria do garantismo penal alcançarmos a máxima efetivação dos direitos fundamentais por meio da implantação do direito penal mínimo, reservando a aplicação da pena privativa de liberdade às condutas sociais efetivamente graves.

Num Estado que se proclama Democrático de Direito, a intervenção mínima do direito penal é questão de suma relevância, já que, como medida mais drástica de pacificação social, sua intervenção somente deve ser reclamada quando os demais ramos do direito não forem suficientemente capazes de salvaguardar o importante bem jurídico da não menos importante gravidade da lesão. ${ }^{39}$

\footnotetext{
37 CANO, Ignacio. Direitos Humanos, Criminalidade e Segurança Pública. In: BRASIL. Presidência da República. Direitos Humanos: percepções da opinião pública: análises de pesquisa nacional. Organização Gustavo Venturi. Brasília: Secretaria de Direitos Humanos, 2010, p. 67.

38 Disponível em: <http://www12.senado.leg.br/noticias/materias/2015/09/17/brasil-caminha-para-serpais-com-maior-numero-de-presos-alerta-diretora-do-depen> Acesso em: 22 set. 2015.

${ }_{39}$ RIBEIRO, Luiz Gustavo Gonçalves Ribeiro; SENESI FILHO, Píer Giorgio. Apontamentos sobre a Importância da Tutela Penal do Ambiente. ARGUMENTUM - Revista de Direito n. 15. Marília - UNIMAR, 2014, p. 307 325. Disponível em: <http://ojs.unimar.br/index.php/revistaargumentum/article/view/91/16> Acesso em: 29 nov. 2015, p. 320.
} 
[...] Transformadas as nossas cadeias em verdadeiros depósitos humanos, criouse um desolador ciclo vicioso: os juízes prendem, na crença de estarem combatendo a criminalidade; porém, quando jovens primários são encarcerados, para sobreviver eles acabam aderindo às organizações criminosas que lá se instalam, devendo favores e fidelidade quando soltos, tornando-se mais fortes. Não há vencedores, todos perdem. $\mathrm{E}$ a única saída para o rompimento desse ciclo vicioso é a completa reforma do Sistema Penitenciário, evitando-se ao máximo, o cárcere, custoso em todos os sentidos. ${ }^{40}$

Na lição de Ferrajoli:

[...] nem as penas privativas de liberdade, nem as penas pecuniárias, nas atuais circunstâncias, parecem estar em condições de satisfazer os fins que justificam o direito penal: umas, por serem demasiado aflitivas, outras, por serem demasiado pouco aflitivas, e tanto umas quanto outras, por serem ineficazes ou, pior ainda, contraproducentes. ${ }^{41}$

O garantismo penal traz em sua concepção a necessidade de repensarmos o sistema penal, com o fortalecimento de penas alternativas à prisão, tendo em vista a grave crise do sistema carcerário, celeiro para violação sistemática dos direitos fundamentais dos presos.

\begin{abstract}
Uma das tarefas mais importantes que se impõe à atual reflexão filosófico-penal é, portanto, a formulação, sobre a base de um repensamento radical da natureza da pena, de um novo sistema de penas, alternativas às vigentes: penas alternativas, tenha-se em conta - e não medidas alternativas - , aptas a satisfazer, como penas principais, o duplo fim do direito penal dentro de uma perspectiva de racionalização e de minimização do sistema sancionador. ${ }^{42}$
\end{abstract}

$\mathrm{Na}$ esteira da mínima intervenção estatal, o desenvolvimento de novas formas de resolução do conflito penal, tal como a aplicação da Justiça Restaurativa como forma de política pública, objetivando que as partes envolvidas no evento criminoso atuem na busca pela solução da celeuma, fortalece a democracia e permite a minimização do estigma social ao criminoso, posto que, proporciona uma melhor compreensão do evento criminoso, assim o processo restauratório, com atuação conjunta do Estado, por meio de um mediador, da própria vítima, e pelo criminoso na resolução do conflito, harmonizando a paz social.

Podemos entender a Justiça Restaurativa com uma reformulação de nossa concepção de Justiça, tendo como objetivos trabalhar a compreensão das

\footnotetext{
${ }^{40}$ DELMANTO, Celso. DELMANTO, Roberto. DELMANTO JUNIOR, Roberto. DELMANTO, Fábio M. De Almeida. Código Penal Comentado: acompanhado de comentários, jurisprudência, súmulas em matéria penal e legislação complementar. $8^{a}$ ed. - São Paulo: Saraiva, 2010, p. 226-227.

${ }^{41}$ Ibid, 2002, p. 330.

${ }^{42}$ Ibid, 2002, p. 330.
} 
pessoas sobre a situação conflituosa para que haja a humanização dos envolvidos, possibilitando a identificação das necessidades geradas pelo conflito/crime e a consequente responsabilização de todos os afetos, direta ou indiretamente, para que, de uma forma ou de outro, se comprometam e contribuam para sua resolução. ${ }^{43}$

Segundo Renato Sócrates Gomes Pinto:

A Justiça Restaurativa baseia-se num procedimento de consenso, em que a vítima e o infrator, e, quando apropriado, outras pessoas ou membros da comunidade afetados pelo crime, como sujeitos centrais, participam coletiva e ativamente na construção de soluções para a cura das feridas, dos traumas e perdas causados pelo crime.

Trata-se de um processo estritamente voluntário, relativamente informal, a ter lugar preferencialmente em espaços comunitários, sem o peso e o ritual solene da arquitetura do cenário judiciário, intervindo um ou mais mediadores ou facilitadores, e podendo ser utilizadas técnicas de mediação, conciliação e transação para se alcançar o resultado restaurativo, ou seja, um acordo objetivando suprir as necessidades individuais e coletivas das partes e se lograr a reintegração social da vítima e do infrator. ${ }^{44}$

A principal vantagem da adoção da Justiça Restaurativa como forma de minimizar a atuação do Estado na repressão penal, efetivando os princípios do garantismo penal neste trabalho expostos, é a diminuição do estigma ao criminoso e dos danos causados pelo cumprimento da pena privativa de liberdade, além de proporcionar o ressarcimento da vítima em relação aos prejuízos causados pelo crime.

A justiça restaurativa é um paradigma baseado em certos valores, como o respeito à participação efetiva do ofensor, da vítima e da comunidade atingida pelo delito. Em lugar de se atribuírem as funções principais do procedimento a especialistas e representantes externos, portanto, essa tarefa cabe as diretamente envolvidos e afetados pelo delito. ${ }^{45}$

\footnotetext{
${ }^{43}$ AGUIAR, Carla Zamith Boin. Mediação e Justiça Restaurativa: a Humanização do Sistema Processual como Forma de Realização do Sistema Processual dos Princípios Constitucionais. São Paulo: Quartier Latin, 2009, p. 109.

${ }^{44}$ PINTO, Renato Sócrates Gomes. Justiça Restaurativa é Possível no Brasil? In: Slakmon, C., R. De Vitto, e R. Gomes Pinto, org., Justiça Restaurativa. Brasília - DF: Ministério da Justiça e Programa das Nações Unidas para o Desenvolvimento - PNUD, 2005. Disponível em <http://www.undp.org/content/dam/aplaws/publication/en/publications/democratic-governance/dgpublications-for-website/justica-restaurativa-restorative-justice-/Justice_Pub_Restorative\%20Justice.pdf > Acesso em: 22 set. 2015, p.19.

${ }^{45}$ KONZEN, Afonso Armando. Justiça Restaurativa e Ato Infracional: Desvelando Sentidos no Itinerário da Alteridade. Porto Alegre: Livraria do Advogado, 2007, p. 62.
} 
Somente com a mudança de paradigma da política criminal, buscando efetivar os direitos e garantias fundamentais dos reclusos, fomentar penas alternativas à prisão, com fundamento no direito penal mínimo, adotando-se com maior vigor os paradigmas da Justiça Restaurativa e programas destinados à educação e profissionalização do egresso a paz social poderá ser alcançada, cumprindo-se a finalidade do direito penal em uma perspectiva garantista.

\section{CONCLUSÃO}

Conforme podemos analisar, o Estado viola de forma sistemática os direitos fundamentais dos reclusos, havendo completa falência do sistema prisional tal como atualmente se apresenta, com abuso do direito de punir por parte do Estado, que causa danos aos reclusos maiores que o próprio cumprimento da pena privativa de liberdade, deslegitimando a justificação para aplicação da pena, além de torná-la extremamente penosa e injustamente aflitiva ao recluso.

À luz da teoria do garantismo penal na perspectiva desenvolvida por Luigi Ferrajoli na obra Direito e Razão: Teoria do Garantismo Penal percebemos que nosso sistema penal possui leis formalmente garantistas, mas substancialmente não protegem os direitos fundamentais dos reclusos, devendo existir uma ruptura de paradigma com as atuais políticas públicas criminais, com objetivo de desenvolvimento de um sistema penal substancialmente garantista.

É dever do Estado, juntamente com a sociedade, buscar alternativas para solução do problema carcerário que enfrentamos em nosso país. Não podemos desviar o olhar da situação precária em que se encontram as unidades prisionais, bem como a violação aos direitos fundamentais dos reclusos.

O desenvolvimento de políticas criminais substancialmente garantistas, elaboradas a partir do ideal da mínima intervenção estatal, reservando-se a aplicação das penas privativas de liberdade às situações de maior gravidade social, a partir da utilização com maior vigor de penas alternativas à prisão e do fortalecimento dos dogmas trazidos pela Justiça Restaurativa, é medida que se impõe diante das aflições desmedidas causadas aos presos pelo cumprimento da pena privativa de liberdade em nosso sistema carcerário, com prisões superlotadas e ambientes indignos. 
Concluímos que o atual sistema penal brasileiro não garante substancialmente os direitos fundamentais do preso, e a forma de execução da pena em nossos presídios não se coaduna com os ideais garantistas, maximizando ao invés de diminuir, os danos causados pela prisão, tornando a pena privativa de liberdade injustificada, diante do abuso do direito de punir por parte do Estado. É necessário repensar o sistema carcerário e as prisões à luz da teoria do garantismo penal, fundamentado no direito penal mínimo e respeito aos direitos fundamentais dos reclusos, como forma de legitimar substancialmente a execução penal.

\section{REFERÊNCIAS}

AGUIAR, Carla Zamith Boin. Mediação e Justiça Restaurativa: a Humanização do Sistema Processual como Forma de Realização do Sistema Processual dos Princípios Constitucionais. São Paulo: Quartier Latin, 2009.

ARANÃO, Adriano. Estado Democrático de Direito, Criminalidade e Violência: O Desrespeito aos Direitos Fundamentais e o Papel da Educação. Revista Argumenta. Jacarezinho, n. 08, p. 215231, 2008. Disponível em:

<http://seer.uenp.edu.br/index.php/argumenta/article/view/105/105> Acesso em: 17 set. 2015.

BATISTA, Nilo. Introdução Crítica ao Direito Penal Brasileiro. 11. ed., Rio de Janeiro: Revan, 2007.

CADEMARTORI, Sérgio. Estado de Direito e Legitimidade - Uma Abordagem Garantista. Porto Alegre: Livraria do Advogado, 1999.

CANO, Ignacio. Direitos Humanos, Criminalidade e Segurança Pública. In: BRASIL. Presidência da República. Direitos Humanos: percepções da opinião pública: análises de pesquisa nacional. Organização Gustavo Venturi. Brasília: Secretaria de Direitos Humanos, 2010.

CARVALHO, Salo de. Pena e Garantias. $3^{\text {a }}$ ed. Rio de Janeiro: Lumen Juris, 2008.

DELMANTO, Celso. DELMANTO, Roberto. DELMANTO JUNIOR, Roberto. DELMANTO, Fábio M. De Almeida. Código Penal Comentado: acompanhado de comentários, jurisprudência, súmulas em matéria penal e legislação complementar. $8^{a}$ ed. - São Paulo: Saraiva, 2010.

DIAZ, Elias. Legalidad - legitimidade en el Socialismo Democrático. Espanha: Editorial Civitas S.A., 1978.

DRAPKIN, Israel. Manual de Criminologia. Tradução e adaptação de Ester Kosovski. São Paulo: Bushatsky, 1978. 
FERRAJOLI, Luigi. Direito e Razão: Teoria do Garantismo Penal. Tradução de Ana Paula Somer Sica, Fauzi Hassan Choukr, Juarez Tavares, Luiz Flávio Gomes. $3^{\text {a }}$ ed. São Paulo: Revista dos Tribunais, 2002.

GIACÓIA, Gilberto; HAMMERSCHMIDT, Denise; FUENTES, Paola Oviedo. A Prisão e a Condição Humana do Recluso. Revista Argumenta. Jacarezinho, n. 15, p. 131-161, 2011. Disponível em: <http://seer.uenp.edu.br/index.php/argumenta/article/view/202/201> Acesso em: 18 set. 2015.

GOMES, Décio Luiz Alonso. Política Criminal Brasileira e o Papel do Ministério Público. In: Ministério Público e Políticas Públicas, Rio de Janeiro: Lumem Juris, 2007, v.1.

GOMES, Luiz Flávio; MOLINA, Antonio Garcia Plabos de. Criminologia. São Paulo: Revista dos Tribunais, 2000.

GRINOVER, Ada Pellegrini. O Processo Constitucional em Marcha. São Paulo: Max Limonad, 1985.

GRECO, Rogério. Curso de Direito Penal. Vol. 1 Parte Geral. Rio de Janeiro: Impetus. 2012.

HUNGRIA, Nelson. Comentários ao Código Penal. Rio de Janeiro: Forense, 1959.

KONZEN, Afonso Armando. Justiça Restaurativa e Ato Infracional: Desvelando Sentidos no Itinerário da Alteridade. Porto Alegre: Livraria do Advogado, 2007.

LEAL, César Barros. Prisão: Crepúsculo de uma Era. Belo Horizonte: Del Rey, 2001.

LOPES JR., Aury. Introdução Crítica ao Processo Penal. Fundamentos da Instrumentalidade Garantista. $3^{\mathrm{a}}$ ed. Rio de Janeiro: Lumen Juris, 2005.

MARCON, Danieli Cristina. A democracia e a Realidade da Execução Penal Brasileira. Revista Argumenta. Jacarezinho, n. 10, p. 199-214, 2009. Disponível em:

<http://seer.uenp.edu.br/index.php/argumenta/article/view/134/134> Acesso em: 17 set. 2015.

PAIVA, Luiz Fábio Silva Paiva. À Espera de Respostas: Reflexões sobre o Trabalho da Justiça Criminal. Revista Dilemas. Rio de Janeiro,n. 4, p. 49 - 82, 2009. Disponível em:

<http://revistadil.dominiotemporario.com/doc/Dilemas4Art2.pdf> Acesso em: 17 set. 2015.

PINTO, Renato Sócrates Gomes. Justiça Restaurativa é Possível no Brasil? In: Slakmon, C., R. De Vitto, e R. Gomes Pinto, org., Justiça Restaurativa. Brasília - DF: Ministério da Justiça e Programa das Nações Unidas para o Desenvolvimento - PNUD, 2005. Disponível em <http://www.undp.org/content/dam/aplaws/publication/en/publications/democraticgovernance/dg-publications-for-website/justica-restaurativa-restorative-justice/Justice_Pub_Restorative\%20Justice.pdf.> Acesso em: 22 set. 2015 .

RIBEIRO, Luiz Gustavo Gonçalves Ribeiro; SENESI FILHO, Píer Giorgio. Apontamentos sobre a Importância da Tutela Penal do Ambiente. ARGUMENTUM - Revista de Direito n. 15. Marília UNIMAR, 2014, p. 307 - 325. Disponível em: 
<http://ojs.unimar.br/index.php/revistaargumentum/article/view/91/16> Acesso em: 29 nov. 2015.

ROCHA, Fernando Antonio N. Galvão da. Responsabilidade Penal da Pessoa Jurídica. Revista de direito Ambiental, São Paulo, v.7, n.27, jul./set., 2002.

SILVA, Marco Aurélio Souza da. POLÍTICA PÚBLICA CARCERÁRIA: UMA INSTITUCIONALIZADA VIOLAÇÃO DE DIREITOS FUNDAMENTAIS IMPULSIONADA PELA CRIMINALIZAÇÃO DAS DROGAS. Revista Eletrônica do Curso de Direito da UFSM. Rio Grande do Sul, v. 9, n. 2, p. 233- 262. Disponível em:

<http://cascavel.ufsm.br/revistas/ojs2.2.2/index.php/revistadireito/article/view/13018/pdf\#.V nb2bF51wRg> Acesso em: 20 dez 2015.

SHECAIRA, Sérgio Salomão. Pena e Política Criminal: A Experiência Brasileira. In SHECAIRA, Sérgio Salomão; SÁ, Alvino Augusto de (Orgs.). Criminologia e os Problemas da Atualidade. São Paulo: Atlas, 2008.

TOURINHO FILHO, Fernando da Costa. Processo Penal. Vol. 1. 34 ed. São Paulo: Saraiva, 2012. WACQUANT, Löic. As Prisões da Miséria. Rio de Janeiro: Jorge Zahar, 2001. 